\title{
ADDITIONAL ARTICLES ABSTRACTED IN ACP JOURNAL CLUB
}

The following articles are abstracted in the Jan/Feb 2005 issue of ACP Journal Club. The declarative title of each abstract as published in ACP Journal Club precedes the article citation.

\section{THERAPEUTICS}

- Review: Antioxidant supplementation does not reduce gastrointestinal cancer

Bjelakovic G, Nikolova D, Simonetti RG, et al. Antioxidant supplements for prevention of gastrointestinal cancers: a systematic review and meta-analysis. Lancet 2004;364:1219-28.

Review: Nicotine replacement therapy is effective in both men and women

Cepeda-Benito A, Reynoso JT, Erath S. Meta-analysis of the efficacy of nicotine replacement therapy for smoking cessation: differences between men and women. J Consult Clin Psychol 2004;72:712-22.

- Review: Foam-based, constant low-pressure mattresses are better than standard hospital mattresses for reducing pressure ulcers

Cullum N, McInnes E, Bell-Syer SEM, et al. Support surfaces for pressure ulcer prevention. Cochrane Database Syst Rev 2004;3:CD001735.

- Review: Pharmacotherapy improves cognitive symptoms in dementia

Santaguida P, Raina P, Booker L, et al. Pharmacological treatment of dementia. Evid Rep Technol Assess (Summ) 2004 Apr; (97):1-16.

- Review: Limited evidence supports the use of atypical antipsychotic drugs in behavioral and psychological symptoms of dementia

Lee PE, Gill SS, Freedman M, et al. Atypical antipsychotic drugs in the treatment of behavioural and psychological symptoms of dementia: systematic review. BMJ 2004;329:75-9.

- Esomeprazole was not better than omeprazole for resolving heartburn in endoscopy-negative reflux disease

Armstrong D, Talley NJ, Lauritsen $\mathbf{K}$, et al. The role of acid suppression in patients with endoscopy-negative reflux disease: the effect of treatment with esomeprazole or omeprazole. Aliment Pharmacol Ther 2004;20:413-21.

- An early invasive strategy reduced death or MI better than a conservative strategy in unstable angina and non-STsegment elevation MI at advanced age

Bach RG, Cannon CP, Weintraub WS, et al. The effect of routine, early invasive management on outcome for elderly patients with non-ST-segment elevation acute coronary syndromes. Ann Intern Med 2004;141:186-95.

- Peginterferon $\alpha$-2a improved the hepatitis $C$ virologic response in concurrent HIV and chronic hepatitis $\mathrm{C}$ virus infections Chung RT, Andersen J, Volberding P, et al. Peginterferon Alfa-2a plus ribavirin versus interferon alfa-2a plus ribavirin for chronic hepatitis C in HIV-coinfected persons. $N$ Engl $J$ Med 2004;351:451-9.

$\checkmark$ Peginterferon $\alpha$-2a improved the hepatitis $C$ virologic response in concurrent HIV and chronic hepatitis $C$ virus infections Torriani FJ, Rodriguez-Torres M, Rockstroh JK, et al. Peginterferon alfa-2a plus ribavirin for chronic hepatitis $\mathrm{C}$ virus infection in HIV-infected patients. $N$ Engl $J$ Med 2004;351:438-50.

- Methylprednisolone caused an increase in death after head injury

Roberts I, Yates D, Sandercock P, et al. Effect of intravenous corticosteroids on death within 14 days in 10008 adults with clinically significant head injury (MRC CRASH trial): randomised placebo-controlled trial. Lancet 2004;364:1321-8.

- Nebulized lidocaine before nasogastric tube insertion reduced patient discomfort but increased risk for nasal bleeding Cullen L, Taylor D, Taylor S, et al. Nebulized lidocaine decreases the discomfort of nasogastric tube insertion: a randomized, double-blind trial. Ann Emerg Med 2004;44:131-7.

- Ezetimibe plus simvastatin lowered lipid levels more than simvastatin monotherapy in primary hypercholesterolemia Goldberg AC, Sapre A, Liu J, et al. Efficacy and safety of ezetimibe coadministered with simvastatin in patients with primary hypercholesterolemia: a randomized, double-blind, placebo-controlled trial. Mayo Clin Proc 2004;79:620-9.

- Long-term use of combination DMARDs did not sustain disease remissions, but delayed joint damage in early rheumatoid arthritis

Korpela M, Laasonen L, Hannonen P, et al. Retardation of joint damage in patients with early rheumatoid arthritis by initial aggressive treatment with disease-modifying antirheumatic drugs: five-year experience from the FIN-RACo study. Arthritis Rheum 2004;50:2072-81.

- Volunteers trained in CPR and the use of automated external defibrillators increased survival after out-of-hospital cardiac arrest

Hallstrom AP, Ornato JP, Weisfeldt M, et al. Publicaccess defibrillation and survival after out-of-hospital cardiac arrest. N Engl J Med 2004;351:637-46.

- A dietitian-led intervention reduced weight and waist circumference in obese patients with type 2 diabetes

Wolf AM, Conaway MR, Crowther JQ, et al. Translating lifestyle intervention to practice in obese patients with type 2 diabetes: Improving Control with Activity and Nutrition (ICAN) study. Diabetes Care 2004;27:1570-6.

\section{DIAGNOSIS}

- Magnetic resonance imaging was more sensitive than mammography for detecting breast cancer in high-risk women Kriege M, Brekelmans CT, Boetes C, et al. Efficacy of MRI and mammography for breast-cancer screening in women with a familial or genetic predisposition. $N$ Engl $J$ Med 2004;351:427-37.

\section{PROGNOSIS}

- Mortality rate from early prostate cancer increased 3-fold after 15 years following the diagnosis

Johansson JE, Andren O, Andersson SO, et al. Natural history of early, localized prostate cancer. JAMA 2004;291: 2713-9. 